\title{
Large Cities, Intangible Consumption and Knowledge Production
}

\author{
Lara Penco*
}

\begin{abstract}
The purpose of this paper is to present the characteristics of the city in the knowledge era. In the knowledge era, we argue that a successful city assumes the role of: A) knowledge hub, because large cities host high tech industries, higher education and research institutions, knowledge intensive business services (KIBS); $B)$ consumer hub, which generates consumption, especially of an intangible nature such as services, culture, entertainment, products which spread culture and knowledge (e.g. fashion and design products). This paper aims to provide a conceptual framework to understand the key-factors - implicit and explicit - useful to the development and success of the city.
\end{abstract}

Keywords: Large Cities; Knowledge Management; Consumer-Hub; KnowledgeHub; Knowledge-Worker; Global Markets

\section{Global Economics, Knowledge Management and the Role of Large Cities}

Economic-social scientific research that considers our cities shows that, in knowledge economics and global economics, the role of large cities is destined to be consolidated because they become command and control centres in the context of global networks (Sassen 1991).

In modern economics, urbanisation tends to strengthen and to become strongly concentrated (McKinsey 2011); empirical evidence therefore invalidates the theories that pointed to the gradual dissolution of the large metropolises, and therefore of all agglomerative phenomena, as a result of the expansion of IT networks (Madon, Sahay S. 2001; Castells 1989, Evers, Gerke, Menkhoff 2010). We are also seeing strong urban changeability, in the sense that the situation regarding top cities changes with the entrance of new cities, primarily in the South and Southeast corners of the world.

The cities that develop in the knowledge age are those that are 'at the service' of the two aspects of a dematerialised economy, in other words the dematerialisation of production and the dematerialisation of consumption. The dematerialisation of the economy is highlighted by the growing significance of knowledge as the key

* Associate Professor of Management, University of Genoa (lpenco@economia.unige.it) 
factor of a company's manufacturing processes (Levitt 1976; Gershuny, Miles 1983; Brondoni 2010). Dematerialisation is also evident in consumption models, in the sense that a growing part of available income is destined to the consumption of intangibles such as services, culture, entertainment, products that incorporate functional services or solutions (Lambin 2009), and cognitive artefacts (books, CDs, DVDs, and so on) which spread culture and knowledge (Rifkin 2000).

The model of the industrial city is designed to disappear, because of the strong geographical dispersion of manufacturing activities in the context of the corporate value chain. Globalisation has also accentuated this phenomenon, postulating new, flexible forms of organisation (Brondoni 2008): following the enlargement of their competitive and operating space, companies typically relocate their manufacturing activities where comparative cost advantages are to be found, while highly knowledge-intensive support activities are maintained in geographical spaces that simplify knowledge-based production.

As a result, the 'top' cities are locations that 'draw together' knowledge-based companies that control dematerialised, highly knowledge-intensive manufacturing processes, and operators who serve the vast demand for intangible assets that is concentrated in large metropolitan areas (Carrillo et al. 2010). In other words, the city's function in the dematerialised economy is focused on filling a dual role, i.e.: as a centre of knowledge creation (knowledge hub), and one that draws together companies that offer intangible consumer products (consumer hub).

\section{The City as a Knowledge-Hub}

Knowledge Management studies have emphasised the role played by the city in knowledge production, supporting the hypothesis that knowledge-based companies try to locate themselves in large urban conurbations. Carrillo (2004) coined and uses the concept of 'knowledge city' to identify a metropolitan area which - like a manufacturing system - is able to simplify the creation of knowledge.

Various efforts to analyse corporate decisions unanimously recognise the strategic significance that metropolitan areas of national and global importance acquire as the chosen locations for knowledge-based companies. Urban development is fuelled by the location decisions of knowledge-based companies, i.e. high tech companies, Knowledge Intensive Business Service (KIBS) companies, the Corporate Headquarters of multinational corporations or even branches of large companies with advanced functions (for example, Research and Development, planning, marketing, etc.). Knowledge-based companies pursue concentrated localisation processes, unlike companies that produce 'operational business services' (rental services, maintenance, call centres, low added value IT services, etc.); the latter tend to be disseminated in the territory where demand exists or cost conditions are more competitive (Turok 2008).

For example, large companies, which are often organised in groups, adopt a huband-spoke structural and spatial configuration; the units responsible for coordinating strategic decisions and for managing the sources of competitive advantage are located in large metropolitan areas, while other units, which carry out activities that are not strategic or are linked more directly to the company's operations are dispersed in 'peripheral' areas, where it may be possible to find resources at a lower cost, or where demand is stronger. The attraction of large 
metropolitan areas for knowledge-based companies can be traced back to economies of agglomeration that produce synergies and interdependence (in terms of relational capital) between units with a high knowledge content and other more qualified activities, which are naturally located in vast metropolitan areas. These include higher training, research and development (universities), some complementary knowledge-based services, financial brokerage, national and international public institutions and existing IT networks. One essential condition, if the city is to emerge as a knowledge hub, is the presence of scientific and technological research centres and qualified training centres, specifically because of the recognised importance of the human factor. The role of universities becomes central because they provide the dual function of research and training, and trigger positive fallout in the territory. One absolutely indispensable factor is that of urban 'mobility' and, above all, access to and from other global hubs.

The urban development of cities, particularly the larger ones, depends on the role played by spatial contiguity and the interaction between knowledge-based companies and the wide range of advanced services available in the central business districts of large metropolitan areas, to transfer non-coded knowledge, which is an essential part of these companies' distinctive competencies, and also requires face to face contacts. In spite of the growing availability of increasingly advanced communications tools, which have helped to reduce the impact of physical distances between economic parties (Krugman 1998; Storper 1985), direct contact between human beings is still a primary and relatively irreplaceable source, because a significant part of competitive advantage, and knowledge transmission is still anchored to tacit transfer models that are simplified by contiguity.

\section{The City as a Consumer-Hub}

In the knowledge age, the development of large cities also appears to be linked to the fact that people prefer to live in the city and/or take advantage of the city.

Although the cost of living tends to be higher in a city than in a smaller town, the existence of a higher class of services to the individual (from entertainment to advanced training, from shopping to personal healthcare) and the presence of urban and intercity transport infrastructure significantly raises the standard of living and improves the perceived quality of life.

Urban centres are defined as consumer cities, in other words as hubs producing services for the consumer (Glasier, Gottilieb 2006) or as entertainment machines (Clark 2003);

The greater density that is created in the city supports forms of cultural consumption and entertainment that are provided by the availability of museums, restaurants, cinemas, theatres, concert halls, and sports centres. These facilities all have high overheads, so they can only be sustained in the presence of the huge critical mass of demand found in large metropolitan areas.

Vast quantitative demand is concentrated in the city and, as we all know, services for the individual are created where demand exists. What is more, the residents of large metropolitan areas show a greater propensity to consume these improved services than the residents of smaller towns (Glaeser, Gottlieb 2006; Turok 2008; Jones et al. 2006). On one hand, the residents of large cities are offered cultural facilities close to their homes, a fact that stimulates the exploitation of these 
services, while on the other, the average cultural level of people who live in metropolitan areas tends to be higher than that of people who live in suburban areas or small towns, as does their income.

Consumers in large cities are not only the residents; they also include commuters, external users of the city like tourists, users of advanced services to the individual (e.g. commercial and leisure services, healthcare) and businessmen.

This increases the critical mass of demand for these services. In line with the central place theory, (Christaller 1933), its role as an attraction increases as the city's hierarchical value increases. In other words, the higher the critical mass of services delivered to the individual, the greater the city's capacity to attract consumers.

The great vitality of cities as consumer hubs has been guided by the location decisions of companies that manufacture 'opportunities' for intangible consumption (obviously in addition to the urban structure and town planning policies). These occasions have acknowledged the city as the privileged location for their 'servuction' (service production) which is connected to the unitary process of production-consumption of certain services. Cities thus become an agglomeration of manufacturers that are positioned in the higher part of the pyramid of personal income.

The development of the role of consumer hub seems to coincide with the development of large multinational organisations in the fields of retailing, entertainment and leisure concerns (Jones and Hills 2002), and the hotel industry. These companies, which operate on a vast scale all over the world with an eye to standardisation, try to find in the individual locations where the service is delivered: i) large catchments of users; ii) similar users (businessmen, congress audiences, metropolitan consumers, etc.), that all cities attract indifferently all over the world, quite unlike small towns whose populations seem to be intrinsically linked to their native environment.

In some cases, cities change their physiognomy. Although the urban and territorial aspects of structural conformation cannot be generalised, ever since the 1990s, numerous organisations have been relocating to suburban areas - for example in business centres created by restructuring abandoned former industrial areas - to allow downtown areas to be exploited as consumer hubs. The centres of large metropolitan areas are increasingly populated by companies that are at the service of residents, and by people who prefer to 'live in the city but work in the suburbs' (Glaeser, Gottlieb 2006). The downtown areas of large cities take on a similar conformation that becomes standardised in large metropolises; they all have the same global malls or megastores of large global brands, which replicate their successful 'servuction' system all over the world. These city centres are then surrounded by suburbs and new 'edge cities', or districts specialising in specific functions, that accommodate advanced service sectors activities and the homes of knowledge workers (Turok 2008; Benninson D., Warnaby G., Medway D. 2007; McKee D.L., McKee Y.A. 2004).

\section{Knowledge-Workers and 'City Demand'}

The role of the consumer city and the knowledge city are connected. 
In the past, London, NY, Tokyo, Singapore, Sao Paulo, etc. - in other words the world's leading global metropolises - have all been productive cities (ports, commercial and/or industrial centres) or administrative centres (for example the capitals of certain emerging countries). However, these cities were not dedicated exclusively to a pre-existing dominant mono-culture, but have succeeded in evolving to reflect the transformations imposed by knowledge economics and global economics. Because of the changes to the levers that underlie competitive advantage, which have driven global companies to delocalise their manufacturing activities, they have become the headquarters of multinational corporations, the point where corporate activities with a high added value are concentrated, and strategic centres of advanced services, and they thus acquire the role of a knowledge hub.

But the 'business' function that is present in these cities is also connected to the function of consumer hub, because they become consumer cities and entertainment machines. The dual role of consumer hub and knowledge hub that the city acquires in the knowledge economy is best expressed by a metaphor: the city can be depicted as a Knowledge Harbour (Edvinsson 2006), a port through which 'talents and knowledge' pass, in other words people who are stores of knowledge and who work to produce knowledge. These people are known as knowledge workers and they form the creative class (Florida 2002). Knowledge workers are employed by the knowledge-based companies in the urban hub and they move where there are good prospects for a good quality of life. International studies that have examined the location decisions of high-tech firms (Malecky, Bradbury 1992), have revealed that the factors deemed most important for the ideal location of these activities are linked to the presence of environmental amenities that can fuel the quality of life. Florida (2002) maintains that the economic development of a region or a city is guided by the location decisions of the creative class, which prefers 'different locations, that are tolerant and open to new ideas', according to the model of the three T's (Technology-Talents-Tolerance). The capacity to create a context that is favourable to creativeness leads to the activation of virtuous circles, because 'talent attracts talents, shaping a density or cluster' (Edvinsson 2006).

The creative class expresses a specific 'city demand'.

Knowledge workers want a city that can stimulate creativity and invention, while it guarantees a very high quality of life thanks to a combination of evolved services. It is the knowledge workers, who constitute the key productive factor in the dematerialised economy, that generate much of the demand for intangible assets, because of their high cultural level and, often, higher available income compared to workers in manufacturing industries and in services with a low knowledge content. They can be defined as knowledge citizens (Carrillo 2004; Yigitcanlar et al. 2007). Boosting the role of the knowledge hub therefore stimulates the growth of consumers of intangible assets that are produced in the metropolis itself. What is more, the concentrated presence of companies and activities that produce intangible assets raises the perceived quality of life in the city, thus making it more attractive to more qualified knowledge workers and, consequently, to more competitive companies. We must take into consideration that numerous companies which are at the service of intangible assets are in turn creative companies, highly knowledge-intensive, which employ growing numbers of knowledge workers (for example design companies, publishing companies, event organisers, etc.). 
The following figure (Figure 1) depicts the dual role played by the 'knowledge city', identifying the players in the creation of the hubs and the crucial role of the knowledge workers who are both players (producing knowledge) and consumers (spending on knowledge assets).

Figure 1. Dual Urban Role in the Intangible Economy

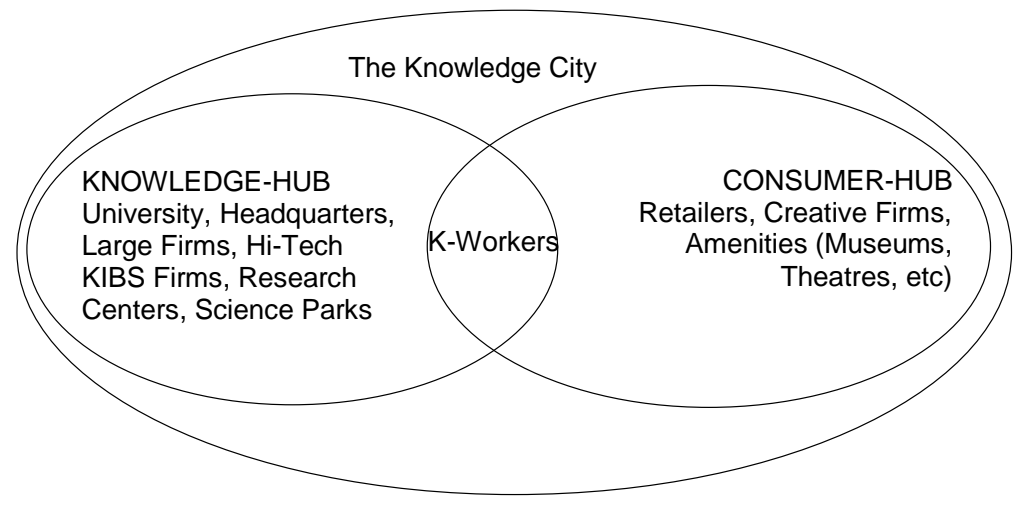

As we have said, the success and development of the urban phenomenon is the outcome of the location decisions of highly knowledge-intensive companies, which prefer the 'knowledge atmosphere' that is created in metropolitan areas thanks to the physical proximity of other similar companies and advanced consumer classes.

As a result, in the knowledge economy, it becomes important for balanced, longterm development, that urban governance should be capable of guaranteeing the dual role demanded of the city.

One very clear example of the need to achieve this balance is the (negative) case of the city of Pittsburgh. The steel city has succeeded in converting its economy to the advanced service sector and has become the home of a prestigious university (Carnegie Mellon University) in the field of IT systems. There has apparently been a successful inversion of Pittsburgh's DNA, from an industrial city to a knowledge hub. The problem is that the city does not currently look attractive in terms of the quality of life, with the result that there is a brain drain of talents to other destinations.

On the other hand, after the industrial or port crisis that has affected them, several Italian cities have set out to reinvent themselves as consumer hubs. These cities, definable as hypermarket-cities, offer value for money that is unbalanced for their populations, and they have gradually lost knowledge workers, because they are full of services with a low added value, which gradually impoverishes the vitality of the town.

In other terms, 'the most globally competitive cities are almost always those in which the men and women who generate a city's intellectual resources are offered professional and personal surroundings that can reasonably ensure their health and safety' (PWC 2011). 


\section{Development Factors of the 'Knowledge City'}

Literature, primarily in the knowledge-management world, has addressed the issue of the definition of factors leading to the development of knowledge cities, identifying strategic and infrastructural factors (for example, political support, urban planning, financial and economic incentives) and operational factors (the existence of wi-fi networks, universities, and city promotion sites) (Carrillo 2004; PWC 2005; Ergazakis et al. 2009; Yigitcanlar et al. 2010). In the light of the above considerations, and in an attempt to classify the most significant factors, a city's success in the knowledge age can be said to be the result of a mix of (Figure 2):

a) implicit factors of development of the city towards activities with a high intangible content;

b) explicit policies for the development of the city as a knowledge city.

In the case of a process triggered by implicit factors, the city is essentially a knowledge city, as a result the spontaneous location of businesses and players that produce knowledge. Urban development is therefore primarily anchored to the location decisions of companies that identify a good knowledge atmosphere in a given city.

Figure 2. The Development Factors of Knowledge Cities

\begin{tabular}{|c|c|c|}
\hline \multicolumn{2}{|c|}{ Implicit development factors } & Explicit promotion policies \\
\hline $\begin{array}{l}\text { knowledge } \\
\text { hubs }\end{array}$ & $\begin{array}{l}\text { - Knowledge-based } \\
\text { agglomerations } \\
\text { - Manufacturing specialisation } \\
\text { in high-tech sectors or } \\
\text { creative industries }\end{array}$ & $\begin{array}{l}\text { - Promotion of knowledge-based } \\
\text { companies } \\
\text { - Creation of knowledge hubs }\end{array}$ \\
\hline$\downarrow$ & $\begin{array}{l}\text { - University excellence } \\
\text { (performance) and } \\
\text { university-company links } \\
\text { - Geographical position of the } \\
\text { city } \\
\text { - Transport networks }\end{array}$ & $\begin{array}{l}\text { - Access compared to other } \\
\text { international hubs } \\
\text { - 'Knowledge city' brand and } \\
\text { policy of city images } \\
\text { - Urban governance: Strategic } \\
\text { plan, City managers, etc. }\end{array}$ \\
\hline $\begin{array}{l}\text { consumer- } \\
\text { hub }\end{array}$ & $\begin{array}{l}\text { - Quality of the city (training; } \\
\text { healthcare and public } \\
\text { services; transport, etc.) } \\
\text { - Size and multi-ethnic } \\
\text { character of the city } \\
\text { - Presence of museums and } \\
\text { cultural/leisure facilities } \\
\text { - Presence of large companies } \\
\text { producing services for the } \\
\text { individual (hotel, restaurants) }\end{array}$ & $\begin{array}{l}\text { - Organisation of large events } \\
\text { - Digitalisation of services } \\
\text { - Town planning policies (new } \\
\text { districts for knowledge workers) }\end{array}$ \\
\hline
\end{tabular}

In the case of a process guided by explicit policies, on the other hand, the city becomes a knowledge hub, because explicit policies to promote it as a knowledge city are inherent in its city governance. In this regard, management theory has recently proposed Knowledge Based Urban Development (KBUD) as a planning/management tool used to promote the development of knowledge cities (Yigitcanlar et al. 2008). 
Implicit and explicit development factors have been extrapolated by literature that focuses on cases of successful metropolitan areas (Edvinsson 2006; Ergazakis et al. 2009; Yigitcanlar et al. 2008; Carrillo 2004; PriceWC 2006).

Some cities have developed primarily on the basis of explicit policies to raise the profile of existing facilities: Barcelona, Turin, Oslo, Gothenburg, Amsterdam, Melbourne (PWC 2005).

'The vision of Barcelona in 2015 is that of a city characterised by the following: a) an economy based on the development of a valueadded and innovative culture depending on the growth of new industries: audiovisuals, design, etc. b) new uses of transport based on the improvement of mobility; c) an education system that can guarantee proper training for our human resources, having notably reduced the number of school leavers by improving the social standing of teachers and increasing their participation in school administration' (PWC 2005).

Other cities, which have always been included in global ranking for the spontaneous existence of implicit development factors, have adopted explicit urban promotion policies in terms of 'knowledge cities', in order to boost their competitiveness and that of the country system that they are a part of, but also to develop in harmony with other neighbouring town centres.

In the latter case, London, which has always implicitly been a knowledge city and in the top group of centres, has recently adopted explicit policies, making the process of city governance increasingly consistent and unitary. The city is the subject of precise, explicit policies to enhance its role as an advanced services centre and a destination for tourism and cultural consumption, which will make London 'the UK's only global city' (HM Treasury 2008; Centre for Cities 2011; Turok 2008).

$\square$ 'The pressures that London and the City of Westminster in particular face are not unique, but it has to be acknowledged that it does share particular characteristics and challenges with a small group of world cities including, among others, Tokyo, New York and Shanghai. The council has always sought to forge partnerships and learn from the experiences of others and recently carried out a 'peer' review of its performance with Baltimore, USA. It has also undertaken the Global City Management Survey with 42 other cities to identify common interests and best practice in managing global cities' ( $P W C$ 2005).

The case of New York, which will maintain its position in the global urban hierarchy, even in the forecasts for 2025 (McKinsey 2011), is particularly interesting. New York's current and future success is the result of a mix of factors related both to the history of a number of activities that are strategic for the global economy and their roots in the urban economy, and to explicit policies to raise the city's profile. 
As we all know, New York City is a command centre and knowledge hub, which specialises in finance and the production of business services (PWC 2011). The urban system of research and university services is very advanced, with 89 higher training institutes that include two of the best U.S. universities (Columbia University and New York University). The system attracts students from all over the world, who represent a catchment of knowledge workers for local companies and the urban economy. In addition, New York is a centre of creativity, in other words of production linked to culture, entertainment, communications and the media: Time Warner, NBC, Disney ABC, Forbes, and Sony all have headquarters in the city of New York (Currid 2006).

With reference to the explicit policies, the mission statement of the city of New York regarding the various profiles of city users is, for companies: 'Working and growing your business in the world's financial capital'; for residents: 'Living and playing in the City that never sleeps'; for tourists: 'Experiencing all the excitement the Big Apple has to offer'; for the relationship between the city and the Administration: 'Accessing city, state, and federal government (www.nyc.gov)'.

In order to boost its role as a knowledge hub, investments to promote innovation are consistent and the universities themselves promote new enterprise through financing and incubator networks. What is more, the system of services to business seems very complex, like the supports that are designed to welcome new entrepreneurial realities:

$\square$ 'Our Administration is committed to making sure that we continue making New York City an even more inviting place to do business. Our five-borough economic development strategy is designed to attract and retain businesses and stimulate job growth by making the City more livable, more business friendly, and more economically diverse ... we are making our City an even more attractive place to live and to work. New York City Economic Development Corporation (NYCEDC) helps companies locate real estate and development opportunities, access capital, and reduce energy costs and taxes' (Michael R. Bloomberg, Mayor of the city, www. nyedc.com).

We point out that the attraction of businesses - typically from the advanced service sector - is irrevocably linked to the enhancement of the quality of life and the role of consumer hub, an essential requirement to attract talents that constitute the propulsive factor of urban development:

'What makes New York City great is that it welcomes talent. It rewards talent, it celebrates talent, it nurtures talent, it encourages talent and, therefore, it attracts talent. ....And people of extraordinary talent get attracted to it because talent likes to be with talent, and it spreads through everything' (PWC 2011). 
New York is a true consumer city and entertainment machine, which is why it attracts new talents.

It is not only the capital of fashion because it is a styling centre and trend setter, but also the world's main fashion retailing market, because all the main fashion brands are represented in the city's streets. Empirical data have shown that, in spite of the economic crisis, the big retailers (fashion stores and eating places belonging to global chains) have continued to expand their presence in every urban district of New York. For the 280 big retailers assessed all over the world, from 2009 to 2010 there was a 4\% increase in the number of points of sale (from 6595 in 2009 to 6859 in 2010). Brooklyn, in particular, expanded intensely in 2010 (Center for an Urban Future 2010). We must also point out that numerous programmes encourage the promotion of the city as a consumer hub, through the promotion of widespread entrepreneurship: the New Business Acceleration Team (NBAT) programme offers consultancy for the creation of new consumer services in the city and 4600 services were supported by the programme in 2010-2011 (www.nyc.gov/nbat).

There are numerous cultural, sports and entertainment opportunities which means that the perceived quality of life is very high, like the city's very image. In spite of the global economic crisis, New York's attraction persists even as a tourist destination, and the hotels recorded room occupancy rates above $90 \%$, increasing prices by an average $10 \%$ to $15 \%$. (www.econpost.com).

\section{6. 'Bipolar' Megalopolises: Global Emerging Issues}

The perspective adopted in this article implicitly associates the Urban World with progress, high tech, well-being, consumption and increasingly with luxury.

However, we must not overlook a critical aspect that is related to the process of urbanisation: the intense poverty that exists 'on the margins' of large global cities, particularly those in the new emerging countries.

There is a term that sums up this critical aspect: the 'slum' or shantytown, a concentration of shacks often put together using waste materials, on the outskirts of large urban agglomerations. In recent years, the development of these slums has been studied by sociologists, politicians and economists, as well as by global humanitarian organisations.

$\square$ 'Almost 1 billion people, or 32 per cent of the world's urban
population, live in slums, the majority of them in the developing world.
Moreover, the locus of global poverty is moving to the cities, a process
now recognised as the 'urbanisation of poverty' (United Nations
Human Settlements Programme 2003).

Since 1970 the growth of the slums has exceeded the growth of urbanisation. This trend, which was typical of large South American cities (for example the 'favelas' di Sao Paulo), is also reflected in the current urban migration processes that lie behind the expansion of the new Asian and African megalopolises. These megalopolises become 'bipolar', with a more 'advanced' side and a much more extensive, albeit less visible, degraded side. The population that is concentrated in the slums, attracted to the metropolis by the prospect of greater urban well-being, is not affected by it, in fact, if anything, it is marginalised. 
$\square$ 'Thus, the cities of the future, rather than being made out of glass and steel as envisioned by earlier generations of urbanists, are instead largely constructed out by crude brick, straw, recycled plastic, cement blocks and scrap wood' (Davis 2006).

This reflection, regarding the existence of a 'hidden face' of the Urban World, poses some important questions regarding the social and environmental sustainability of the model of the large global metropolis, and the role which urban governance, individual national systems and global organisations can play to create better balanced conditions of urban development.

In such a critical framework, we also have to examine the possible roles (and responsibilities) of the companies whose organisational and location decisions have triggered the process of urban migration, and all that implies.

\section{Bibliography}

Bennison David, Warnaby Gary, Medway, Dominic, The Role of Quarters in Large City Centres: a Mancunian Case Study, in International Journal of Retail and Distribution Management, vol. 35, n. 8, 2007, pp. 626-638. http://dx.doi.org/10.1108/09590550710758612

Brondoni Silvio M., Intangible, Global Network and Corporate Social Responsibility, in Symphonya. Emerging Issues in Management (symphonya.unimib.it), n. 2, 2010, pp. 6-24. http://dx.doi.org/10.4468/2010.2.02brondoni

Brondoni Silvio M., Market-Driven Management, Competitive Space and Global Network, in Symphonya. Emerging Issues in Management (symphonya.unimib.it), n. 1, 2008, pp. 14-27. http://dx.doi.org/10.4468/2008.1.02brondoni

Carrillo Francisco J., Capital Cities: a Taxonomy of Capital Accounts for Knowledge Cities, in Journal of Knowledge Management, vol 8, n. 5, 2004, pp. 28-46. http://dx.doi.org/10.1108/1367327041058738

Carrillo Francisco .J., Metaxiotis Kostas, Yigitcanlar Tan, Urban, Regional, National and Global Knowledge Capital, in Journal of Knowledge Management, vol. 14, n. 5, 2010, pp.631-634. http://dx.doi.org/10.1108/13673271011074809

Castells Manuel, The Informational City. Information, Technology, Economic Restructuring and the Urban-Regional Process, Basil Blackwell, London, 1989.

Center for an Urban Future, A Chain Reaction: This Year's Borough-by-Borough Analysis of New York City's Largest Retailers, in New York by the Number, www.nyfuture.org, 2010.

Clark Terry, Urban Amenities: Lakes, Opera, and Juice Bars - Do They Drive Development?, in Clark, Terry (ed.), The City as an Entertainment Machine, JAI Press/Elsevier, New York, 2003.

Currid Elisabeth, New York as a Global Creative Hub: A Competitive Analysis of Four Theories on World Cities, in Economic Development Quarterly, vol. 20, n. 4, 2006, pp. 330-350. http://dx.doi.org/10.1177/0891242406292708

Davis Mike, The Planet of Slum, Verso, London, 2006.

Edvinsson Leif, Aspects on the City as a Knowledge Tool, in Journal of Knowledge Management, vol. 10, n. 5, 2006, pp. 6-13.

http://dx.doi.org/10.1108/13673270610691134

Ergazakis Emmanouil, Ergazakis Kostas, Metaxiotis Kostas, Charalabidis Yannis., Rethinking the Development of Successful of Knowledge Cities: an Advanced Framework, in Journal of Knowledge Management, vol. 13, n. 5, 2009, pp. 214-227. 


\section{http://dx.doi.org/10.1108/13673270910988060}

Ergazakis Kostas, Metaxiotis Kostas, Psarras John, Askounis Dimitris, A Unified Methodological Approach for the Development of Knowledge Cities, in Journal of Knowledge Management, vol. 10, n. 5, 2006, pp. 65-78. http://dx.doi.org/10.1108/13673270610691189

Evers Hans-Dieter, Gerke Solvay, Menkhoff Thomas, Knowledge Clusters and Knowledge Hubs. Designing Epistemic Landscapes for Development, in Journal of Knowledge Management, vol. 14, n. 5, 2010, pp. 678-689. http://dx.doi.org/10.1108/13673271011074836

Gershuny Jonathan, Miles Ian, The New Service Economy. The Transformation of Employment in Industrial Societies, Frances Pinter, London, 1983.

Glaeser Eduard L., Gottlieb Joshua D., Urban Resurgence and the Consumer City, February 2, 2006, Preliminary Draft, 2006.

Jones Peter, Hiller David, Urban Leisure Complexes in UK: Planning and Management Issues, Management Research News, vol. 25, n. 11, 2002, pp. 73-83.

Krugman Paul, The Role of Geography in Development, Paper prepared for the Annual World Bank Conference on Development Economics, Washington, D.C., April 20-21, 1998.

Lambin Jean-Jacques, Capitalism and Sustainable Development, in Symphonya. Emerging Issues in Management (symphonya.unimib.it), n. 2, 2009, pp. 3-9.

http://dx.doi.org/10.4468/2009.2.02lambin

Lehmann Martin, Fryd Ole, Urban Quality Development and Management, in International Journal of Sustainability in Higher Education, vol. 9, n. 1, 2008, pp. 21-38. http://dx.doi.org/10.1108/14676370810842166

Levitt Theodore, The Industrialization of Service, Harvard Business Review, vol. 54, n. 5, 1976, pp. 63-74.

Madon Shirin, Sahay Sundeep, Cities in the Developing World. Linking Global and Local Network, in Information Technology \& People, vol 14, n. 3, 2001, pp. 273-286. http://dx.doi.org/10.1108/EUM0000000005832

Marmolejo Duarte C., Transforming Metropolitan Barcelona: between the Postindustrial and the Knowledge city, Paper Presented to w011 - Metropolitan Dynamics: Urban Change, Market and Governance, ENHR, International Conference, Rotterdam, 2007.

McKee David L., McKee Yosra A., Edge Cities, Urban Corridors and Beyond, in International Journal of Social Economics, vol. 31, n. 5/6, 2004, pp. 536-543. http://dx.doi.org/10.1108/03068290410529362

McKinsey Global Institute, Urban world: Mapping the Economic Power of Cities, 2011.

PriceWaterhouseCooper, Cities of the Future, Global Competition, Local Leadership (http://www.pwc.com), 2005.

PriceWaterhouseCooper, Cities of Opportunities (http://www.pwc.com), 2011.

Rifkin Jeremy, The age of access, Tarcher Putnam New York, 2000.

Sassen Saskia, Global Cities: New York, London, Tokyo, Princeton University Press, Princeton, NJ, 1991.

Sassen Saskia, The Urban Complex in a World Economy, International Social Science Journal, $\mathrm{n}$. 139, 1994, pp. 43-62.

Turok, Ivan, A New Policy for Britain's Cities: Choices, Challenges, Contradictions, in Local Economy, vol. 23, n. 2, 2008, pp. 149-166. http://dx.doi.org/10.1080/02690940801976224

United Nations Human Settlements Programme. The Challenge of Slums - Global Report on Human Settlements, Earthscan Publications Ltd, London and Sterling, VA, 2003.

Warnaby Gary, Davies Barry J., Commentary: Cities as Service Factory? Using the Servuction System for Marketing Cities as Shopping Destinations, in International Journal of Retail \& Distribution Management, vol. 25, n. 6, 1997, pp. 204-210. http://dx.doi.org/10.1108/09590559710175953 
Wong Caroline Y. L., Millar Carla C. J. M., Choi Chong Ju, Singapore in Transition: from Technology to Culture Hub, in Journal of Knowledge Management, vol. 10, n. 5, 2006, pp. 79-91. http://dx.doi.org/10.1108/13673270610691198

Yigitcanlar Tan, Baum Scott, Horton Stephen, Attracting and Retaining Knowledge Workers, in Journal of Knowledge Management, vol. 11, n. 5, 2007, pp. 6-17. http://dx.doi.org/10.1108/13673270710819762

Yigitcanlar Tan, Velibeyoglu Koray, Martinez-Fernandez Cristina, Rising Knowledge Cities: the Role of Urban Knowledge Precint, in Journal of Knowledge Management, vol. 12, n. 5, 2008, pp. 8-20.

http://dx.doi.org/10.1108/13673270810902902 